\title{
Countergifts and affidation
}

\section{Countergifts}

$\mathrm{T}$

HE EXCHANGE of material and spiritual countergifts was a method of ensuring the security of the land transfers which charters record. Historians view their significance in differing ways. Emily Tabuteau's pragmatic interpretation argues that contemporary society received both juridical and spiritual benefits through gift exchange and that material countergifts given to relatives of a donor represented a form of compensation for loss of land. ${ }^{1}$ According to John Hudson, countergifts re-emphasised the mutuality between parties, that is, between donor(s) and beneficiary, could be symbolic and were usually voluntary. ${ }^{2}$ This approach is similar to that of Barbara Rosenwein, who stressed the relationships between donors which were created when gifts were exchanged. ${ }^{3}$ Dominique Barthélemy argues that social class was exhibited when precious objects such as gold rings were exchanged. ${ }^{4}$ Stephen White also argues that the social context of gift exchange is important because countergifts were tangible expressions of specific social hierarchies and served to define the place of individuals within kin groups. ${ }^{5}$ Further White stresses that as land transfers became more like sales by the early thirteenth century, and with the introduction of warranty clauses, the need for laudatio parentum declined because an effective method of cutting off family claims had been achieved. ${ }^{6}$

This discourse on the meaning of countergifts rightly debates the juridical implications and their symbolisms within social contexts. Little has specifically been written which directly addresses the problem of interpreting countergifts as a guide to the power of noblewomen, because the above historians are, for example, interested in the meaning of gift exchange ceremonies, or of the consent of relatives, rather than the power of women. White's suggestions that countergifts served to memorialise 
social status, were an aid to memory and were always exchanged to secure a gift are a useful way to consider the significance of countergifts as a guide to women's power. ${ }^{7}$ Thus countergifts may also have had an important role in the creation of social memory, in which women had a role in commemoration of the gens. ${ }^{8}$ This memorialisation role of the countergift is illustrated in the text of a charter given by Alice de Gant in 1176 whereby she received one gold ring for confirmation of her husband's grant of her dower. The charter's closing protocol states, Et in testimonium et in rememorationem dederunt michi predicti monachi unum annulum aureum. ${ }^{9}$ Although few historians have addressed the significance of countergifts as a guide to the power of noblewomen, Lady Stenton's suggestion that countergifts to noblewomen represented 'signs of uneasy social conscience' on the part of beneficiaries when their husbands disposed of land they had acquired through marriage at least recognised the possibility that there were differences in the meaning of countergifts given to men and women. For Lady Stenton countergifts were a 'personal gift' which were to deter women's future claims to lands alienated by male kin. ${ }^{10}$

The following discussion, based on a wide survey of twelfthcentury charters and cartularies, will consider the importance of material, as distinct from spiritual, countergifts given to secular noblewomen as a guide to their power. The analysis will be put into the context of an appraisal of the importance of gender, lordship and the way that family connections were indicated through countergifts. This will be achieved through a consideration of the importance of the type(s) of countergift that women received, and, where appropriate, this will be put into a comparative framework with those received by men. Thus it is argued that an analysis of countergifts should properly be studied in sociocultural contexts but with an awareness of the impact of gender and the demands of tenurial lordship. Lordship is important because countergifts symbolised and reinforced hierarchy in lordship and were thus a social barometer of those involved in patronage. Likewise patterns of land tenure related to the female life cycle - dowry, dower and inheritance are significant because this was increasingly important for the definition it gave to the relationship between lords and tenants, and the powers of husbands and wives or widows to control property. However, the right by which a woman held land is not always made clear in the texts of charters. Crucially, it is also imperative that the meanings and symbolisms of countergifts should be set into a paradigm which acknowledges that changes in diplomatic may have affected documentary forms. Thus as a gauge of social realities this assessment of countergifts is placed in a

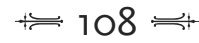


framework similar to that established in the previous chapter to analyse witnessing.

Although both men and women received an array of items as countergifts in twelfth-century England, male recipients of countergifts tended to receive horses, armour, hunting birds or money. ${ }^{11}$ Barthélemy's study of the Vendome 1050-1150 found, for example, that, out of fiftyfive men at Marmoutier, twenty-one received objects relating to equitation. Barthélemy points out that it was not seemly for the nobility to receive farm animals as countergifts and that luxury objects were procured through the acquisition of countergifts. ${ }^{12}$ Stephen White pointed out that benefactors of monastic institutions received objects as varied as clothing, jewellery, animals, grain and wine as well as both small and large amounts of money. ${ }^{13}$ Both rightly stress the important influence of social status upon the nature of countergifts that were given to patrons. Yet gender also impacted on the sorts of gifts that were exchanged. For example, although in the twelfth century noblewomen did on occasion receive horses, only two examples have hitherto been located, and both recipients were heiresses. In 1160-70 Emma de 'Selveleia' received, with the consent of 'H.', her second husband, two marks and a palfrey when she gave lands worth $15 s$ to Luffield Priory. ${ }^{14}$ When $c .1170-5$ her son and heir by her first marriage subsequently confirmed the grant, he received $20 s$ and a palfrey. ${ }^{15}$ Matilda countess of Warwick received $15 \mathrm{~s}$ and a palfrey from Henry du Puiset, her nephew by an illegitimate daughter of her father, when she enfeoffed him with lands worth a quarter of a knight's fee $c .1175-94{ }^{16}$ The sparsity of the evidence relating to the receipt of gifts such as horses as countergifts suggests that objects and accoutrements associated with horses were deemed more appropriate for male recipients. This was possibly related to ideas about lordship as a male role, and also military functions, which of course were generally associated with men.

Where noblewomen received objects of symbolic value, their participation could be linked with their tenurial claims to the land alienated. Circa 1149-56 Rohais, the wife of Gilbert de Gant, received a gold ring in return for a confirmation charter concerning her dower lands that had been granted to Kirkstead Abbey by her husband. ${ }^{17}$ In 1150-60 William earl of Albermarle granted to his niece Eufemia, wife of Robert de Brus (II), her marriage portion, which she then granted to him for life in return for a gold ring and some money. ${ }^{18}$ Eufemia's uncle thus retained control of family land, and perhaps provided her with a wedding ring, since the lands were of her marriage portion, and dowry in the form of a sum of money to take with her to her marriage. Circa 1160-70 when 
Walter of Ingram sold land to Rievaulx Abbey he received fifteen marks, and his wife, Holdeard, who had consented to the sale, which concerned lands of her dower, received a gold ring. ${ }^{19}$ Alice de Gant, as well as spiritual benefits, received a gold ring for her confirmation charter to Fountains Abbey of lands of her dower which had been previously granted by her husband, Roger de Mowbray. ${ }^{20}$ In 1194-95 Atheliza Holebagge received one gold brooch from Gilbert de Reding in return for a grant in hereditary right of land worth $2 s$ per year. ${ }^{21}$ In $1189-1220$ Juliana of Shudy Camps received a gold ring from her younger son, Moses, when she gave him lands for which he had to render $\mathfrak{E} 1$ of cumin yearly. ${ }^{22}$ When he received lands from his elder brother, Moses gave in return a sparrowhawk. ${ }^{23}$ Gender, social status and land tenure interacted to define the sorts of gift that noblewomen received.

Both noblemen and noblewomen also received sums of money as countergifts, indeed Tabuteau found that in Normandy this was the most common form of material countergift. ${ }^{24}$ In the late twelfth century Reginald de Meiniers and his wife confirmed their grant in frankalmoign of various lands to the abbey of Robertsbridge. The lands came to Reginald by right of his wife, Matilda, and he thus gave her $\mathfrak{E}_{12}$ Anjou of rent out of his mill at Meiniers because she quitclaimed all her land in England to her husband. The monks of Robertsbridge paid $\mathfrak{E} 120^{2}$ for the concession. ${ }^{25}$ In another example the countergift apparently functioned as payment of relief. Matilda de Avranches in the late twelfth century received one gold mark for making recognition by charter of a vassal entering lands by right of inheritance. ${ }^{26}$ When Basilia, daughter of Ailrich, c. 1210-15 quitclaimed lands to Robert, son of Matilda, she finalised the agreement in the court of her lord. For the quitclaim and her abjuratione Robert gave her $6 s$ and his wife, Anne, gave Basilia a robe, peplum. ${ }^{27}$ This example shows that both husband and wife were involved in giving countergifts to seal a specific transaction and that the wife of Robert was involved in the proceedings at court even though the text of the charter itself does not specifically mention to whom the quitclaim was made. That is, the text states that Basilia quitclaimed to Robert, not to Robert and his wife. The countergifts and stipulation of services related to dressmaking were the foundations of an economic agreement agreed between 'lord' and vassal. When Emma, daughter of Wimund Ravenildescroft, gave countergifts to Muriel de Munteni and subsequently to her daughter Lecia, she secured her tenure of lands by a combination of money and goods in payment. When Muriel granted the lands to Emma she received a peplum, and her daughter Lecia, on confirming this gift, some sandals. The lands were to be held by a render of $2 s$ 
annually after Emma's death by her heirs. ${ }^{28}$ These agreements of Lecia de Munteni and her mother, Muriel, with Emma Ravenildescroft suggest the variety of countergifts and that a countergift could apparently be a payment.

When husbands and wives were involved in joint actions both could receive countergifts; for example, c. 1167-78/79 Hawise countess of Gloucester and her husband, Earl William, both received gold rings from Richard de Lucy when Earl William enfeoffed Richard. ${ }^{29}$ In 1192 Ralph fitz Geoffrey and his wife Matilda received twenty marks for their quitclaim made in the king's court from the monks of Eynsham Abbey. ${ }^{30}$ These examples suggest ways that wives were conjointly recognised alongside their husbands when they acted in lordship. The specific place of women within familial social hierarchies and their social status in the wider community were both symbolised and confirmed when different amounts of money or different objects were exchanged. For example, in 1135-40 Robert de Sarz and his wife Ragnahild gave lands to Fountains to be held by a render of half a mark yearly. The grant had been given by the counsel and with the goodwill of Ragnahild. ${ }^{31}$ In the same period Thurstan archbishop of York confirmed this to Fountains Abbey and Robert received one mark and Ragnahild received $3 s^{32}$ In the late twelfth century William of Lanvallay received four marks for his acknowledgement of a tenant's right to land, whilst his wife received two talents. ${ }^{33}$ When in the same period Stephen Canute of Whittlesford disposed of lands relating to his wife's marriage portion he received $14 \mathrm{~s}$ and his wife Matilda received $12 d .^{34}$

Since countergifts reveal social hierarchy such as the place of the individual within the kin, or such as those between husbands and wives, it follows that symbolic countergifts will reflect gender differences related to the meaning and power of those roles. Circa 1160 Regenerus the Painter gave Hugh de Camville and his wife, Christina, a countergift, Hugh received a scaccarium (chessboard or exchequer cloth) and Christina wimplaria (wimple/s). Whilst it may be the case that this gift 'transcended normality' it also shows gender divisions. ${ }^{35}$ Hugh received a countergift which was of practical use, Christina an item of clothing which was gender-specific, since veils were used to cover the hair of married women. If the scaccarium was an accounting cloth, this countergift also reflects the predominance of his economic interest in the joint interest of husband and wife. Husband and wife here acted together to grant land to a painter, indicating patronage of an artist in an aristocratic household in which husband and wife were both involved. There are other examples which suggest that countergifts symbolised an 
individual's place in the family and in lordship. When in 1123-53 Hugh fitz Richard enfeoffed John of Kington in certain lands in Preston Bagot, Warwickshire, John in return gave him three marks, his son William half a mark and a sword, and Margaret, his wife, half a mark. ${ }^{36}$ Margaret, the wife of Hugh fitz Richard, received a payment worth less than that of her husband, but nevertheless her place as wife of the lord was recognised; the gifts of a sword and money received by the son and heir were symbolic of his social status, function and place in the familial and social hierarchy. When Roger earl of Warwick confirmed this gift he received in return a white brachet, a hunting bitch. ${ }^{37}$ When the widow of Earl Roger, Countess Gundreda, confirmed this the cartulary makes no mention of a countergift. ${ }^{38}$ Her son, Earl William, however, received an iron-grey horse and five marks for his confirmation charter. ${ }^{39}$

There are therefore complex interrelated factors which explain the sorts of countergifts given. These include the type of transfer the countergift reinforced as well as such contexts as lordship, gender, social status and family links. Circa 1150-80 Ralph de Aincurt, Matilda, his wife, William, his son, and Robert gave to John the clerk and Basilia, the daughter of Ralph, four acres of land in Hanworth (Lincolnshire). In return John gave one mark to Ralph and his sons and Matilda received a 'certain gold ring' and a coverlet of Lincoln green. ${ }^{40}$ Henry II $c .1175$ confirmed a sale of a house in Rouen whereby Bernard Comin and his wife, Hawise, received $\mathfrak{E}_{140}$ Anjou and a palfrey. ${ }^{41}$ In the late twelfth century Gunnilda, the wife of Robert Sturmi, with the assent of her husband, confirmed his previous grant to the monks of Margam Abbey. For this concession she received four marks, a lambskin for a pellice and twenty sheep. ${ }^{42}$ This grant concerned eighty acres of Gunnilda's dower lands, and since it was her dower land that was sold Gunnilda had to quitclaim, or make public recognition of the sale by charter to ensure the finality of the sale: the countergifts were thus in reality the price of the sale. It is difficult to know the precise negotiations which preceded the grant which the charters ratify, but the above examples suggest that wives acted in lordship with their husbands and this was recognised through countergifts, and that the socio-legal contexts affected the type of gift. Thus the nature of the transaction, as well as the land transacted, were equally important: a sale, or exchange of lands for specified 'countergifts' which were in reality payments, would obviously be a way of raising funds for a specific need such as financing a journey to Jerusalem, ${ }^{43}$ or for combating poverty in widowhood, ${ }^{44}$ or gaining goods or services. ${ }^{45}$ It is more difficult to assess whether there was a decline in the symbolic value of countergifts. It is easier to detect that 
an increasing number of transactions in the twelfth century were sales. When Cecilia, daughter of Sabelina, granted a confirmation charter to Southwark Convent and Priory (Surrey), the countergifts given to her and her sons were given in gersum. The payments, however, reflected proprietary interest and status; Cecilia received five marks, her three sons, Geoffrey, Lawrence and John, one gold bezant respectively. This charter was sealed with four seals, and they too reflect hierarchy, since Cecilia's seal is the largest and the seals of her sons are graded in descending size. ${ }^{46}$ In the early thirteenth century Margaret de Bray, as Margaret, daughter of Aluffi de Merch', granted a confirmation charter of gifts made to St Mary's Betelesden. For her confirmation and quitclaim the monks gave her one mark, Miles her son and heir half a mark and his brothers similarly half a mark. These amounts have the character of monetary payments, which reinforced hierarchy in the differing amounts given but also symbolised her proprietary interest in the property conveyed. ${ }^{47}$

The above examples illustrate that countergifts could symbolise complex meanings and that noblewomen received countergifts in a variety of contexts. The conjugal relationship of husband and wife could be defined in the countergift, as in the de Camville example. ${ }^{48}$ Noblewomen also received countergifts from their children, for example, from son to mother, as in the case of Juliana de Shudy Camps. ${ }^{49}$ Matilda de Percy received a countergift from her half (illegitimate) nephew. ${ }^{50}$ Sisters could participate in transactions with their male kin such as brothers. When, for example, Beatrice de Chevrecourt acted with her brother Ralph, between 1144 and 1155, with the consent of Ralph's sons, to give the town of Barnsley to the Cluniac priory at Pontefract in preparation for his entry into the monastery, the place of each was clearly evaluated in the countergifts that they received. The monks would appoint three monks, one for their mother, one for Beatrice and one for Ralph. Ralph would enter the monastery at his will and receive a small cash allowance and a monk's habit annually. In return for this concession Beatrice received ten marks, and Ralph received three, a monk's tunic and boots yearly. His sons too received gifts: Jordan received a palfrey, and Richard five marks. Their lord, Henry de Lacy, and his mother were present when the grant was agreed. ${ }^{51}$ The example of Eufemia, the niece of William earl of Albermarle, suggests that nieces could also be the recipients of countergifts from within the family. ${ }^{52}$ The family hierarchy was mapped out in economic terms, which could also have a symbolic aspect; this tends to confirm White's suggestion that kinship positions were demonstrated by countergifts. 
Yet countergifts also illustrate networks of hierarchy beyond the family since women received countergifts from tenants/vassals. In this respect they also reinforced the place of women within social hierarchies within the community. When Gunnilda de Sturmi received her sheep and sums of money from Margam Abbey she did so as lord, with claims to the lands, and as wife: both roles empowered her socially and economically. ${ }^{53}$ Thus the other hierarchy illustrated in the above examples is that of lordship, patronage and the administration of land. When Matilda de Percy enfeoffed her father's illegitimate son she acted as patron and landholder, operating in a wider family context. ${ }^{54}$

Precisely because ideas about gender underlay the way that women held land, that is, on the basis of the female life cycle, it underpinned ways that they participated in land transfers. Just as witnessing was gendered male, so countergifts when they expressed social status could also symbolise gendered ideas about the place of women in lordship. Where countergifts were of a monetary value in those transactions which had the character of a sale, women's subordinate position was demonstrated by the lesser amount that they received, but also their claim was symbolised and reinforced. Countergifts served to demonstrate the subordinate position of a wife to her husband in society, but also paradoxically placed her at the centre of agreements whilst enshrining her position as a subsidiary but intrinsic party to them. Female participation could thus be predicated on their tenurial interests and thus women appear in transactions as witnesses or as the recipients of countergifts.

\section{Affidation}

The affidation ceremony was, like witnessing and the exchange of countergifts, a method of ensuring the security of an agreement. The ritualised public nature of affidation was briefly discussed by Herbert Fowler, who commented on the oddity of these occasions. He stated that affidation overlapped the beginning of warranty and that, according to Pollock and Maitland, 'it may look like an oath; we may think it implicitly contains all the essentials of an oath; but no relic or book or other thing is sworn upon and no express words of imprecation are used'. Affidation was a personal act which further strengthened the intent of the donee and was part of a ceremony to ensure the security of the gift. Indeed, Fowler noted that the affidation worked to ensure no future claims on the land by the parties or to warrant the land and that an 'affidation in the hand' was an 'ancient and solemn formality ... by which a man placed his soul or honour in the hand of another should 
he fail to observe his part' ${ }^{55}$ Evidence of female participation in twelfthcentury affidation ceremonies will be discussed as a guide to the power of noblewomen in the context of an analysis which considers the impact of gender, social status and lordship.

Circa 1166-76 Asceria, the widow of Asketil de Habton, made her affidavit in the hand of Bertha de Glanville, the wife of Ranulf de Glanville. ${ }^{56}$ The charter recorded the occasion with particular care. The fact that Bertha's husband is listed as first witness suggests his presence at the ceremony, and therefore that she acted in a role which was related to his, but not necessarily in his place. There are six female witnesses listed, and female affidation is clearly often accompanied by female witnessing. The phraseology employed is concise: Hanc donationem firmiter tenendam et fideliter observandam manu propria affidavi in manu vicecomitisse, videlicet Bert[he] uxoris vicecomitis Rannulfi de Glanvilla. In addition, however, the use of the vicecomitissa title is suggestive that Bertha acted in an official capacity, and a way of expressing this was found. Certainly Bertha's role was rooted in her marital status and this was gendered because her husband's position of sheriff was not predicated on his marital status. The grant concerned lands which had been granted by Bertram de Bulmer to Asketil, son of Gospatric de Brageby, in 114766. His widow, Asceria, confirmed the grant to Rievaulx, since the lands in question were part of her dower. She also in the same charter accepted an exchange of lands made by her husband which also concerned lands that were hers by right of dower.

The evidence suggests that when women, whether as wives or widows, made an affidation they could, on occasion, make it in the hand of a woman. Circa 1175 Richard le Moine notified that his wife Alice had quitclaimed half a hide in Wardon which was of her dower. She made her affidation in the hand of Lecia, wife of William de Kirkby. ${ }^{57}$ The witnesses were March', presbiter, and Eularia and Lecia, sisters of the same, and Eva, wife of Jordan Inchegale. Alice made her affidation in the hand of her sister, which suggests that this was a public ceremony designed to forestall the claims of kin to the lands granted. A further example confirms the above patterns. Circa 1170-80 William Lenveise and his wife Denise sold and confirmed to Wardon Abbey whatever they held of its fee at Wardon, for the use of the hospices of the poor, by consent of Robert, son of Alfred. For this the abbey gave them three marks from the moneys of the hospice of the poor and $2 s$ to Denise, his wife. ${ }^{58}$ William made his affidation in the hand of William de Bedford, Denise in the hand of Lady (domine) Eularia. This conjoint grant and sale to the abbey was enacted in the court of the abbot, by the grant of 
Robert fitz Alured. There is some slippage within the text between verbs which describe both the actions of William and Denise, for example the opening address uses verbs in the plural: William and Denise uendidimus et presenti carta confimauimus. Yet it was William who enacted the symbolic action which transferred seisin: Et hanc cartam obtuli pro me et pro uxore mea super altare sancte Marie abbacie de Wardon. There were six female witnesses, the lady Eularia, who received the affidation of Denise, Milisent, the wife of Malclerc, who also witnessed, Agnes, the wife of the clerk, Anschetill, Ralph the Clerk, the husband of Emma, and Emma, along with their daughters Alice and Olympiade. The monks gave them three marks and $2 s$ to Denise. In another charter, granted in the same period, William Lenveise per grantum et per uolantatem Dionisie uxoris mee gave a croft and a messuage and a little land at Old Wardon at the rent of $1 d$ for the use of the hospice of the poor; for this the abbey gave them $12 s 4 d$ as gersum from the moneys of the hospice. Denise's role was recorded separately from that of her husband, and when she participated in the ceremony she again made her affidation in manu domine Eularie whereas her husband made his in the hand of William scriptoris. The same witnesses attested this charter, according to the cartulary copy.$^{59}$ This evidence of female affidation indicates that when women made an affidation they were likely to do so in the hand of a woman. However, c. 1210 Alienora, the daughter of William de Monte Alto and Amicia de Swinton, gave land to Fountains she made her affidation in curia de Richemund. Thus the location of the ceremony was recorded, but to whom she swore her affidavit is not. ${ }^{60}$ The affidation clause is immediately followed by a sealing clause to enhance further the security of the charter.

When Walter Bech and Agnes, his wife, made an agreement to exchange certain lands with Kirkstead Abbey in 1162, and licensed their men to do so, they both promised to warrant the exchange, and they both made an affidation in the hand of Walter abbot of Bardney. ${ }^{61}$ This would seem to suggest that husband and wife could conjointly make an affidation. Most interestingly, however, there is an additional witness list to the affidation of Agnes which is exclusively female. ${ }^{62}$ Thus although Agnes, acting with her husband, made her affidation in the hand of the abbot the witnesses to the occasion were all women. When in the mid to late twelfth century Beatrice, the widow of Joslan of Ingleby, confirmed her husband's gifts and granted lands of her dower to Kirkstead, she made her affidation in the hands of Edith, the wife of Brian de Welletun. Edith also witnessed the charter along with two other women, who are listed after nine male witnesses. ${ }^{63}$

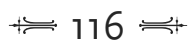


Affidation was made by women in a public arena to disbar future claims and ensure the security of a gift. There is little evidence of women of the high nobility, such as countesses, making or receiving affidations. The highest-ranking woman who was involved in this public ceremony so far uncovered is Bertha de Glanville, vicecomitissa, and her role was to receive, not to make, the affidation. This suggests that social status mattered when making affidation, as did gender. Where women made affidations they usually did so in the hands of women, and on these occasions the participation of women in the ceremony was witnessed by women.

The concern of beneficiaries and patrons to ensure the security of their transactions explains the development of certain features of charters, including the inclusion of relatives in consent clauses to disbar future claims, the public ritual acts of placing gifts on altars, affidation, warranty, witnessing and countergifts. Warranty clauses are an indication of the concern to ensure good lordship, and were also a mechanism which neutralised family claims to land transactions. ${ }^{64}$ Warranty clauses routinely appear in charters from the late twelfth century. It is possible that as early as 1140 specific clauses within charters appeared which ensured that both sexes were warranted against; ${ }^{65}$ however, there is no simple timetable of documentary change in the late twelfth century. ${ }^{66}$ Certainly it can be established that in the late twelfth century warranty clauses were developed which contained a phrase whereby the warrantor bound him/herself to uphold claims contra homines et feminas. ${ }^{67}$ This development of what may be termed double warranty clauses against men and women to disbar claims from either sex shows that women were recognised as posing a threat to the security of gifts in claiming land, and may be related to the development of co-parceny - the division of land among female heirs. It confirms Hudson's view that warranty was primarily a way of securing a grant from an outside challenge. ${ }^{68}$

The exchange of material countergifts, affidation ceremonies and warranty clauses were methods intended to ensure the security of charters. The material countergifts that women received publicly confirmed noblewomen's societal position and place within the kin. They also confirmed the bonds of lordship and thus the relationships of both men and women with patrons and with beneficiaries. Social status mattered when countergifts were exchanged, as did gender in some instances. This is directly related to social status since noblewomen received gold rings or luxury objects, lower status women received sums of money, as did lower status men. Social status and gender also affected the way that affidation ceremonies were enacted. Only lower status women 
participated to make an affidavit: noblewomen received it. This study thus suggests that White, Tabuteau and Barthélemy are right to see countergifts as reflective of juridical concerns, social status and important for memorialisation of ceremonies. ${ }^{69}$ If, however, the complex symbolisms of countergifts combined with the legalistic role of warranty and affidation, as discussed in the previous chapter concerned with female witnessing, were to be set into a reappraisal of the way that documentary forms changed and developed in the late twelfth century, ${ }^{70}$ it would be clearer whether and how countergifts changed in symbolic meanings, and how ideas about gender affected this development. ${ }^{71}$ The evidence here provides only a fragmentary and partial view of the nature of women's power because charters only imperfectly record the countergifts, warranty and affidation. It is important that the interactions of gender, social status and land tenure upon the power of twelfthcentury noblewomen are incorporated into the analysis. If this is done, the involvement of women in the exchange of countergifts, warranty and affidation ceremonies develops the picture already presented in Chapters 4 and 5. Not only can we see charters as a representation and narrative of the power of countesses, or an indication of the involvement of women as witnesses, but also as an indication of the interaction of women of different social status and its importance, with kinship and lordship, in shaping noblewomen's identities.

\section{Notes}

1 E. Z. Tabuteau, Transfers of Property in Eleventh-century Norman Law (Chapel Hill NC: University of North Carolina Press, 1988), pp. 114-19, 133. Tabuteau emphasises that the receipt of a countergift did not necessarily indicate consent to a transaction, and that charters which mention countergifts were in the minority: ibid., pp. 115, 118 .

2 J. G. H. Hudson, Land, Law and Lordship in Anglo-Norman England (Oxford: Clarendon Press, 1994), pp. 165-6. For the symbolic meaning of objects attached to charters to secure conveyances see M. Clanchy, From Memory to Written Record: England, 1066-1307 (London: Edward Arnold, 1979; 2nd edn, Oxford: Blackwell, 1993), pp. 37-43, 254-60. H. B. Teunis similarly argues that countergifts were voluntary, but focuses on religious institutions and sees countergifts as a method by which they attempted to encourage benevolent behaviour from patrons: 'The countergift in caritate according to the cartulary of Noyers', Haskins Society Journal, 7 (1997 for 1995), 88.

3 B. Rosenwein, To be the Neighbor of Saint Peter: The Social Meaning of Cluny's Property, 909-1049 (Ithaca NY and London: Cornell University Press, 1989), pp. 136-43.

4 D. Barthélemy, La Société dans le comté de Vendôme: de l'an mil au XIV siècle (Paris: Fayard, 1993), p. 690. 
5 S. D. White, Custom, Kinship and Gifts to Saints: The Laudatio Parentum in Western France, 1050-1150 (Chapel Hill NC: University of North Carolina Press, 1988), pp. 27, 166.

6 Ibid., p. 203.

7 Ibid., pp. 26-8; Tabuteau similarly argues that countergifts were given as an aid to memory: Transfers of Property, p. 118.

8 M. Innes, 'Memory, orality and literacy in an early medieval society', Past and Present, 158 (1998), 1-36, at p. 5; J. L. Nelson, 'Gender and genre in women historians of the early Middle Ages', in L'Historiographie médiévale en Europe (Paris, 1991), 150-63, at p. 151.

9 Mowbray Charters, no. 131.

10 D. M. Stenton, The English Woman in History (London: Allen \& Unwin, 1957), p. 31.

11 Ranulf (II) of Chester received a roan warhorse from his butler in return for land (1141-3): Chester Charters, no. 55. Ranulf (III) received two greyhounds called Lym and Libekar for a concession to his hostarius (1194-1202): ibid., no. 271. Roger de Mowbray received a gold ring from his clerk in 1154-70: Mowbray Charters, no. 331; and for confirming a charter Roger received a palfrey (1154-79): ibid., no. 333. For 10os Nigel de Mowbray confirmed his father's grant (1160-79): ibid., no. 334. A fine and quitclaim of 1205 made in the king's court resulted in Robert abbot of Eynsham, giving ten marks, a palfrey and and an unmewed goshawk in of a dispute: Eynsham Cartulary, 1. no. 183.

Barthélemy, La Société dans le comté de Vendôme, p. 695.

White, Laudatio Parentum, p. 27.

14 Luffield Priory Charters, 1. no. 107. This grant was a confirmation of a previous conjoint gift made by Emma and her first husband, Eustace: ibid., no. 114 (1140-60). She granted another charter to the monks with her third husband c. 1170-75: ibid., no. 106. Emma was heiress to fees in Berkshire, Suffolk and Silverstone, Northamptonshire: ibid., 267.

Ibid., no. 111.

$E Y C$, 11. no. 62

BL, Harl. Ch. 50. F. 32; for her seals see Appendix 1, nos 49A and 49 B.

18 EYC, 3. no. 1352.

$19 E Y C$, 2. no. 710; see also ibid., no. 712, where Walter Ingram gave William, son of Richard, the land of William, the father of Richard's wife. Walter Ingram's wife, Holdeard, received one mark from William, son of Richard, since the land was of her dowry. Thus the dowry was passing between the husbands of two sisters. Mowbray Charters, no. 131. Roger's charter: ibid., no. 120.

21 Cartulary of Holy Trinity Aldgate, no. 687.

Early Charters of Waltham Abbey, no. 188. See another grant by Juliana, ibid., no. 189, with a similar countergift to seal the transaction.

23 Ibid., no. 192.

24 Tabuteau, Transfers of Property, pp. 21, 27.

25 The lands conveyed were Matilda's marriage portion, given to her by Ingelram de Frescheville: Calendar of Charters and Documents Relating to Robertsbridge, no. 11. For King Richard's confirmation of this and other gifts see ibid., no. 47. Devon Record Office, 1262/M T531 (Fortescue Deeds) (DBC).

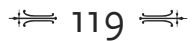


The Early Records of Medieval Coventry, ed. P. Coss (British Academy, Records of Social and Economic History, new ser., 11, 1986), no. 29.

28 Clerkenwell Cartulary, nos 65, 73 (c. 1193-96). For a further discussion of these charters see below, Chapter 8 .

29 Gloucester Charters, no. 115.

30 Eynsham Cartulary, 1. nos 108, 110. For Matilda de Lucy's charter confirming the agreement, probably made at the same time, see ibid., no. 109.

$31 E Y C$, 1. no. 65: cum consilio et bona volunatate uxoris mee.

32 Ibid., no. 66.

33 Before 1180 or 1185-1215: Early Charters of Waltham Abbey, no. 165. Other examples, Eynsham Cartulary, nos 170, 172.

34 Early Charters of Waltham Abbey, no. 146.

35 Oxford Charters, no. 54. Hudson, Land, Law, and Lordship, p. 166, following Stenton, considers the gift to be of a chessboard and some veils. There is some doubt in different editions of this charter whether Christina received just one veil or more.

36 Reading Abbey Cartularies, ed. B. R. Kemp (2 vols, Camden Society, 4th ser., 31, 33, 1986, 1987), 1. no. 577. For the significance of swords as symbolic objects see Clanchy, Memory to Written Record, pp. 38-41. John's wife, as Agnes de Preston, in her widowhood was involved in a dispute with the monks of Reading over part of this land, which was her dower, which was settled by Final Concord in the king's court at Oxford in August 1193. By an assize of mort d'ancestor her three daughters and co-heiresses settled a dispute with the monks: Reading Abbey Cartularies, 1. nos 583, 584 .

37 Reading Abbey Cartularies, 1. no. 578.

38 Ibid., no. 579.

39 Ibid., no. 580. The horse was probably worth 16s; see ibid., no. 652.

40 Leeds Archives, Ingilby Records, no. 249.

41 CDF, no. 32.

42 National Library of Wales, Aberystwyth, MS Penrice and Margam 11. Circa 1203 Isabella countess of Warenne granted lands to a tenant after the death of her husband, Earl Hamelin, for which she received one mark; she here acted as a superior 'lord' in the context of enfoeffment: BL, Add. Ch. 24,634; for her seal see Appendix 1, no. 132. EYC, 11. no. 68; also printed, Transcripts of Charters relating to the Gilbertine Houses of Sixle, Ormsby, Catley, Bullington and Alvingham, ed. F. M. Stenton (Lincoln Record Society, 18, 1922), no. 15. Roger de Mowbray raised considerable sums of money after the rebellion of 1174-75: Mowbray Charters, nos 120-2, and see xxxi.

44 EYC, 2. no. 807, where Agnes de Rotessa, in 1188, made a grant in magna necessitate mea.

45 As in the case of Muriel and Lecia de Munteni: see above, p. 103 n. 73.

46 BL, Harl. Ch. 50. B. 33. This seal is discussed in Chapter 7.

47 Ibid. Ch. 84. I. 22 (early thirteenth-century); for her seal see Appendix 1, no. 82. Margaret was the wife of Roger de Bray, who with her consent made grants to the monks at Old Wardon (Bedfordshire): Cartulary of Old Wardon, no. 97, c. 11901200.

48 See above, n. 35 .

49 Early Charters of Waltham Abbey, no. 188. 
$50 \quad E Y C$, 11. no. 62.

51 EYC, 3. no. 1771.

52 Ibid., no. 1352.

53 National Library of Wales, Aberystwyth, MS Penrice and Margam 11. As did Cecilia, daughter of Sabelina, and Margaret, the wife of Roger de Bray; see above, p. 113 See also Lecia and Muriel de Munteni, as discussed above, Clerkenwell Cartulary, nos 65,73 .

54 EYC, 11. no. 62.

55 Fowler, Cartulary of Old Wardon, p. 8, citing Pollock and Maitland, History of English Law, 2. 186-90.

56 EYC, 2. no. 780.

57 Cartulary of Old Wardon, no. 280.

58 Ibid., no. 299.

59 Ibid., no. 300.

60 Vyner deeds, deposited at Leeds Archives, no. 4939; for her seal see Appendix 1, no. 86 .

61 BL, Harl. Ch. 45. H. 7; Danelaw Charters, no. 172.

62 Ibid.; they are Nogga, the wife of Richard, son of Henry, Clementia, the niece of Walter Bech, Sigga, the wife of Osbert, and Lucy, the wife of Robert de Wispintuna.

63 BL, Harl. Ch. 49. H. 3; Danelaw Charters, no. 214 (temp. Henry II); the other women who witness are Eda, the wife of Goseclin de Areci, and Emma de la Kernel. Beatrice received 20 from the monks and a cow for her remission.

64 Hyams, 'Warranty and good lordship', pp. 443-5; White, Laudatio Parentum, p. 203; Hudson, Land, Law and Lordship, pp. 162-5.

65 Mowbray Charters, no. 35 (suspicious).

66 Hyams, 'Warranty and good lordship', p. 474.

67 BL, Harl. Ch. 48. F. 27; BL, Harl. Ch. 83. D.30, Cartulary of Old Wardon, nos 25, 110, 248, 305, 308, 319 (late twelfth-century); Clerkenwell Cartulary, nos 24 (1190-94), 58 (20 March 1190), 104 (Michaelmas 1196); EYC, 2. no. 807 (c. 1188). Other late twelfth to early thirteenth-century examples: Early Charters of Waltham Abbey, nos 69, 172, $175-6,178$.

68 Hudson, 'Anglo-Norman land law and the origins of property', p. 58; for warranty, ibid., pp. 51-8.

69 See nn. 1, 4 and 5 above.

70 Hyams, 'Warranty and good lordship', pp. 470-1.

71 Bates, 'Prosopographical study', p. 90. 